JOURNAL OF INTERAMERICAN STUDIES AND WORLD AFFAIRS is published four times annually in cooperation with Transaction Periodicals Consortium by the University of Miami North-South Center for the Institute of Interamerican Studies, P.O. Box 248205, Coral Gables, FL 33124-3027. Copyright 1994 (ISSN 0022-1937) by the University of Miami, Institute of Interamerican Studies. All rights reserved. No portion of the contents may be reproduced in any form without written permission of the publisher.

Authorization to photocopy items for internal or personal use, or the internal or personal use of specific clients, is granted by the University of Miami, Institute of Interamerican Studies, for libraries and other users registered with the Copyright Clearance Center (CCC) Transactional Reporting Service, providing that the base fee of 25 cents per copy, plus 10 cents per copy page, is paid directly to CCC, 21 Congress St., Salem, MA 01970. This consent does not extend to other kinds of copying, such as for general distribution, for advertising or promotional purposes, for creating new collective works, or for resale.

The JOURNAL is abstracted or indexed in Hispanic American Periodicals Index, Historical Abstracts, International Political Science Abstracts, Public Affairs Information Service, Current Contents, Social Sciences Citation Index, Social Sciences Index, ABC POL SCI, and United States Political Science Documents; it also is available on $16 \mathrm{~mm}$ microfilm, $35 \mathrm{~mm}$ microfilm, and $105 \mathrm{~mm}$ microfiche from University Microfilms, Inc., Ann Arbor, Michigan.

SUBSCRIPTIONS: Per year institutional rate is $\$ 80.00$; individuals, $\$ 42.00$; continental US students only (with proof of current registration), $\$ 20.00$. Application to Mail at Second Class Postage Rates is pending at Coral Gables, FL, U.S.A.. Rates for international subscribers are $\$ 104.00$ for institutions, $\$ 68.00$ for individuals. All European and Israeli orders should be sent to Swets Publishing Service, Heereweg 347, 2161 CA, Lisse, The Netherlands.

BACK ISSUES, business communications, permissions, subscriptions orders, and change-of-address requests (send old label or address along with your new address) are to be sent to Journal of Interamerican Studies and World Affairs, Dept. 4010, Transaction Periodicals Consortium, Rutgers University, New Brunswick, NJ 08903.

ADVERTISING RATES and information are available from the advertising director at the above Transaction Periodicals Consortium address (telephone: 908-932-2280); all copy is subject to publisher's approval.

CIAIMS for undelivered copies must be made no later than three months following the date of publication. If loss occurs in transit, the publisher will replace missing copies as reserve stocks permit. 
EDITORIAL CORRESPONDENCE: Address all correspondence and permission requests to the Journal of Interamerican Studies and World Affairs, University of Miami, P.O. Box 248205, Coral Gables, FL 33124-3027, U.S.A..

\section{ATTENTION AUTHORS}

The Journal of Interamerican Studies and World Affairs publishes articles that deal primarily with contemporary USLatin American relations, US foreign policy regarding Latin America, Latin American nations' relations with each other and the rest of the world, and Latin American internal affairs when such have clear implications for US foreign policy. The editors also welcome from scholars and public figures worldwide articles about political, economic, cultural, and social aspects of Latin American Interrelationships.

This is a refereed journal. All submissions are sent to qualified reviewers to determine acceptance for publication.

Send manuscripts in duplicate to address below, typewritten and double spaced. Place footnotes, references, tables, and charts on separate pages following current Journal style.

Upon acceptance, you will be asked to provide all tables and charts accompanying the manuscript on computer disks (either IBM-compatible or Macintosh) in addition to two complete, double-spaced printouts of disk material. Tables, charts, maps or other graphic materials will not be used unless provided on computer disks and in a file that is separate from that of the text. Columns in tables and charts should use tabs instead of individual spacing. A brief biographical sketch of the author should accompany the final manuscript.

Correspondence regarding book reviews should be directed to the Book Review Editor at the Journal of Interamerican Studies and World Affairs, University of Miami, P.O. Box 284205, Coral Gables, FL, 33124-3027. 


\section{Luso-Brazilian Review}

RETURN THIS AD AND RECEIVE A FREE SAMPLE ISSUE.

Editors: Mary L. Daniel

Robert M. Levine
Published: 2 / yr.

ISSN: 0024-7413

Features Portuguese, Brazilian and Lusophone African culture, with special emphasis on scholarly works in the social sciences, linguistics and literature.

Rates:

Individuals (must pre-pay):

Institutions:

Foreign postage:

Airmail:
$\$ 27 /$ yr.

$\$ 77 /$ yr.

$\$ 8 / \mathrm{yr}$.

$\$ 11 / \mathrm{yr}$.

We accept MasterCard and VISA. Canadian customers please remit $7 \%$ Goods and Services Tax.

Please write for a free brochure and back issue list to:

Journal Division, University of Wisconsin Press,

114 North Murray Street, Madison, WI 53715 USA

Or call, 608-262-4952, FAX 608-262-7560 
THE NORTH-SOUTH CENTER promotes better relations among the countries of the Western Hemisphere through programs of cultural and technical exchange, public outreach, research services, education programs, online information, and publications.

NORTH-SOUTH, THE MAGAZINE OF THE AMERICAS A forum for debate of the major issues on the North-South agenda. A bimonthly publication, NorthSouth covers North American-Caribbean-Latin American relations, trade, business, economics, politics, the environment, and social issues. Interviews, analyses, articles, legislative updates, and country-by-country business and political briefs are regularly featured."

JOURNAL OF INTERAMERICAN STUDISS AND WORID AFFAIRS

For over thirty years the Journal has provided informed perspectives on U.S.-Latin American international relations."

NORTH-SOUTH CENTER REPORTS North-SOuth Focus is a country report series with a cross-cutting thematic approach oriented around the North-South agenda. The North-South Issues series provides an analysis of the major economic, social, and political developments that impact North-South relations. 305-284-8914.

INFO-SOUTH LATIN AMERICAN INFORMATION SySTEM reviews more than 1,200 publications for contemporary social, political, and economic information on Latin America. It provides citations, online abstracts, and financial statistics, as well as an online directory of names, associations, and businesses in the news in Latin America. 305-284-4414 or call toll-free 800-752-9567.

THE North-SOUTH Agenda PAPERs disseminate the latest research on the Hemisphere in a working paper format. 305-284-8914.

The Curan Information System The comprehensive data base on Cuba, including information on current politics, policies, economic data analyses and forecasts, demographic profiles, and future investment risk-analysis studies. Call 305-284-8906 for more information.

- Order from Transaction Periodicals Consortum, Rutgers University,

[.] New Brunswick, New Jersey 08903. Phone 908-932-2280.

Fax 908-932-3138. Postage is extra for foreign subscriptions.

ThE NorTh-South Center/The University of MIAMI 1500 Monza Avenue, P.O Box 248205, Coral Gables, FL 33124-3027 Telephone 305-284-6868 / Fax 305-284-6370 


\section{SOVIET-CubaN ALIIANCE 1959-1991}

By Yuri Pavlov

"Former Soviet Ambassador and Foreign Ministry official Pavlov bas written the most autboritative treatment of Soviet-Cuban relations so far available. It is likely to become one of the ten most useful books on socialist Cuba" - Cole Blasier, former chief of the Hispanic Division, Library of Congress

During the Cuban Missile Crisis in 1962, Yuri Pavlov was asked on some occasions to interpret for Nikita Khrushchev. In 1982, he was appointed Soviet ambassador to Costa Rica, and in 1987, he became head of the foreign ministry's first Latin American Directorate and was responsible for Soviet-Cuban bilateral relations. Pavlov draws

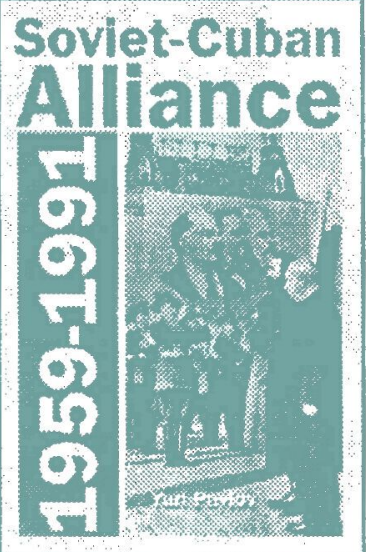
upon these experiences to give both a personal and a political account of the history of the Soviet-Cuban alliance and speculates about the future relationship of Cuba and Russia.

The alliance began soon after 1959 when Fidel Castro came to power. The cost of the Soviet Union's support of the Cuban revolution upset many Soviet citizens, who were suffering economically. The alliance went through a severe strain as a consequence of the Cuban Missile Crisis. Pavlov believes that the two nations became allies only as a result of the Cold War; when this period passed into history, the Soviet Union no longer needed nor could it afford Cuba's dependent relationship. It became ruinous economically and embarrassing politically. The disintegration of the Soviet Union only accelerated, and finally completed, the process of separation.

Pavlov sheds light on the features of Soviet-Cuban relations that influenced Russian policy toward the United States. He provides the first eyewitness appraisal of the history of this alliance as well as the present confused and contradictory Russian policy toward Cuba. Soviet-Cuban Alliance is an essential resource for political scientists, scholars of international relations, and Cuba and Soviet area specialists in search of accurate information on Russian and Soviet thinking about Castro's Cuba.

ISBN 1-56000-691-9 (paperback) 288 pages, US $\$ 18.95$ (plus shipping)

\section{A University of Miami North-SOUTH CENTER BoOK} Distributed by Transaction Publishers, Rutgers University New Brunswick, New Jersey 08903 (908) 932-2280 